\title{
INJURY SURVEILLANCE AT A LEVEL I TRAUMA CENTRE IN JOHANNESBURG, SOUTH AFRICA
}

\section{Judith C Bruce}

MSc Nursing

Senior lecturer, Department of Nursing Education, University of the Witwatersrand

Corresponding author: brucejc@therapy.wits.ac.za

\section{Shelley Schmollgruber}

MSc Nursing

Lecturer, Department of Nursing Education, University of the Witwatersrand

\section{Jocelyn Eales}

Chief Professional Nurse, Trauma Casualty, Johannesburg Hospital

\section{Jasmin Gassiep}

Senior Tutor, Chris Hani Baragwanath Nursing College

\section{Vanessa Doubell}

Tutor, Chris Hani Baragwanath Nursing College

Keywords: trauma centre; injury surveillance; injury severity; TRISS method

\begin{abstract}
An analysis of 16357 trauma patients seen over a one year period at the trauma casualty of an academic hospital in Johannesburg was carried out to determine the profile of injuries sustained by victims in the Johannesburg region. A retrospective survey was conducted between January and December 2001 to compile a composite trauma morbidity and mortality profile, and to create baseline data for future comparison. The objectives of the survey were: to describe the frequencies, distribution and categories of injuries; to assess, on admission to the trauma casualty, the severity of injuries according to the TRISS method; and the outcomes and/or placement of patients after initial treatment in the trauma casualty. Guided by a structured checklist, data were collected by reviewing trauma registers and patients' documents. The TRISS method was used to determine injury severity and descriptive statistics were used to present and describe the results.

A preview of the survey results indicates that males are a high-risk category for trauma, particularly over weekends, during their nocturnal activities. More than two thirds of all patients sorted in the 16-35 year age group. Injuries to the limbs and head and neck regions accounted for the highest percentage of cases with assault or interpersonal violence a major cause in an estimated $70 \%$ of cases. More than $60 \%$ of a random sample of 163 patients had sustained serious injuries with an ISS between 16 and 75; the majority however had a survival probability (PS) of $>50 \%$. This paper describes the methodology and results of the survey in relation to a proposed long-term injury surveillance project.
\end{abstract}

\section{OPSOMMING}

'n Analise van 16357 trauma-pasiënte gesien in 'n een-jaar periode in die trauma-ongevalle van 'n akademiese hospitaal in Johannesburg, is uitgevoer ten einde 'n profiel van beserings wat opgedoen is deur slagoffers, in die Johannesburg-area, te bepaal. 'n Retrospektiewe opname is gebruik om 'n omvattende trauma-morbiditeit en mortaliteitsprofiel saam te stel, en om basislyndata vir toekomstige vergelykings te genereer. Die fokus van die 
opname was gerig op frekwensie, verspreiding en kategorisering van beserings, die ernstigheidsgraad van beserings (ISS), asook die uitkoms en plasing van pasiënte na inisiële behandeling in die trauma-ongevalle. 'n Gestruktureerde kontrolelys is gebruik om data te versamel deur die evaluering van traumaregisters en dokumentasie van pasiënte. Die TRISS-metode is gebruik om te bepaal wat die ernstigheidsgraad van die beserings was. Verder is beskrywende statistiek gebruik om die data aan te bied en te beskryf. Die resultate van die opname dui aan dat mans in die hoërisiko-kategorie vir trauma val, veral tydens naweke en gedurende nagtelike aktiwiteite. Meer as tweederdes van alle pasiënte val in die 16- 35 jaar ouderdomsgroep. Beserings aan die ledemate, kop-en nekarea het in die meeste gevalle voorgekom. In ongeveer $70 \%$ van die gevalle was aanranding of interpersoonlike geweld die hoofoorsaak van hierdie beserings. Meer as 60\% van 'n ewekansige steekproef van 163 pasiënte het ernstige beserings opgedoen, met ' $n$ ISS van tussen 16 en 75. Die meerderheid het egter ' $n$ oorlewingsmoontlikheid $\left(P_{s}\right)$ van $>50 \%$ gehad. Hierdie artikel beskryf die metodologie en resultate van die opname in die konteks van 'n voorgestelde projek vir die waarneming van langtermynbeserings.

\section{INTRODUCTION AND BACKGROUND}

Trauma is ranked as the second most important cause of all deaths in South Africa, with violence related deaths as a central feature. A homicide rate of 61 per 100000 , compared to that of 10 per 100000 in the United States of America (USA), places the South African society among the most violent in the world (Marais, 1998:1). The collective impact this has on the economy, the health services and societal stability is incalculable. The majority of trauma patients are young and productive participants in the country's economy, and who, as a result of their injuries, incur high personal, social and economic costs. In the USA trauma has been described as the most serious public health problem (Cardona, Hurn, Mason, Scanlon \& Veise-Berry, 1994:28), a position which the South African trauma scenario is rapidly surpassing.

Locally, trauma is a significant community health and primary health care problem, yet trauma care services and the Ambulance and Emergency Medical Services (AEMS) are generally not recognised as important links in the chain of primary health care (Fuhri, 1998:36). The infancy stage in which the Primary Health Care (PHC) services find themselves increases the strain on hospital services mainly due to geographic inaccessibility, to unavailability (in service hours) and the irregular supply, and sometimes the lack of essential drugs, equipment and appropriately skilled personnel at PHC clinics. Continued budgetary cuts to hospital services have made it virtually impossible to provide primary emergency care to the most needy.

As to be expected there has been no proportionate decrease in the incidence of trauma and emergencies consistent with a decrease in resources. The persistently high and ever increasing levels of trauma pose a serious threat to the continuance of adequate trauma services and are fast eroding the capacity and morale of trauma personnel at all levels of care. An academic hospital in Johannesburg, considered as the USA equivalent of a level 1 trauma centre, is no exception where an estimated 16000 to 18000 patients are treated annually at the trauma casualty. Of these patients, approximately $10-12 \%$ are so severely injured that they require resuscitation. Further diagnostic procedures, multidisciplinary surgical interventions and intensive care admission, exacerbate patient morbidity.

The literature review that follows incorporates the characterisation of trauma centres, an overview of the nature and severity of injuries and a description of the TRISS method of analysing injury severity.

\section{LITERATURE REVIEW}

By definition a trauma centre operates in a designated hospital and provides resuscitation and other forms of surgical and non-surgical emergency treatment (Cardona et al. 1994:29). Trauma centres are further stratified into three levels according to specific criteria, which relate to the functions/services provided, physical facilities and clinical expertise available. Criteria for level II and level III trauma centres are variable but a common feature is the referral system, which exists between these levels and a level I trauma centre. Level I trauma centres provide 24-hour emergency services by qualified trauma surgeons, physicians and 
nurses, and are active in teaching, research and systems development. The development of efficient and cost effective trauma systems is thus a major function and can be effected and sustained by appropriate surveillance mechanisms to determine comprehensive trauma patterns and profiles. In surveying injuries, Van der Spuy (1996:10) is of the opinion that a simple head count of trauma cases would not suffice. Important considerations include injury distribution, categories and outcomes, and the severity of injury, most of which are determined by the mechanism of injury, and necessitate a cursory overview.

\section{Mechanism of injury}

Relating to the injuring force and subsequent tissue response, the mechanism of injury is useful to explain the nature of the injury, identify common combinations of injury, and predict eventual outcome (Cardona et al. 1994:94) according to the severity of injury. How the body responds to the injuring force is determined by the interplay between biophysical factors, for instance, force and velocity, the shape of the object and tissue rigidity. The force inflicting injury may be blunt or penetrating, causing a varying amount of energy to be delivered to the area of contact, at varying velocity.

Blunt or non-penetrating trauma is caused by direct or indirect forces from traffic accidents, falls, assaults and contact sports. Direct impact delivers a concentration of energy to the point of contact, causing greatest injury at the site. An indirect force on the other hand, causes energy to be dissipated internally over a larger area. The extent of the damage in both instances however, is dependent on the force velocity; the greater the velocity, the greater the damage to tissue. Dependent on the cause, blunt trauma usually involves a combination of forces, notably acceleration, deceleration, shearing and crushing forces. Hence multiple injuries are common (Cardona et al. 1994:95).

In penetrating trauma the mechanism of injury is the energy generated and dissipated by the object such as a knife, into the surrounding tissues (Cardona et al. 1994:104). The extent of the damage is directly proportional to the amount of energy created (kinetic energy) of which velocity in an important factor. Whilst several factors, such as distance from the force, tissue density and site of penetration, are considered in estimating the extent of tissue damage, it is generally agreed that high-velocity forces have the potential of inducing injuries with a high index of severity. Common types of penetrating injuries include stab wounds, gunshot wounds and impalements from falls and forceful collisions with an object.

Apart from biomechanics, associated risk factors such as age, sex, geographic location, alcohol consumption and many more, play a significant role in trauma and injury severity. Within the context of this study, the age and sex of trauma patients were established. The question of age is found to be particularly significant in trauma, based on two assumptions around demography and morbidity and mortality. Firstly, older people are less inclined to sustain injuries than their counterparts younger than 50 years, and secondly, injuries in the older patient are likely to be more severe and carry a higher mortality than in younger victims. Age as an important determinant of human physiological reserve and hence patient survival, is discussed with the TRISS method of analysing injury severity.

\section{Injury severity: The TRISS method}

The TRISS method gives a physiological and anatomical index of injury severity based on the Injury Severity Score (ISS), the Revised Trauma Score (RTS), the patient's age and whether the injury was blunt or penetrating (Woodford, 2001:5). The ISS assigns numerical scores to body regions injured, in order to determine the extent of multiple injuries and correlating these with mortality risk. The ISS ranges from 1 to 75 . When the ISS is 25 , the mortality risk is minimal (approximately $25 \%$ ), but thereafter the mortality risk increases almost linearly with the injury score; a score of above 70 being close to $100 \%$ mortality.

The second parameter, the Revised Trauma Score (RTS), combines coded values of respiratory rate, systolic blood pressure and Glasgow coma scale to provide the extent of physiological derangement as a result of trauma. The coded values in each of these three parameters (maximum value 4), are multiplied by a weighting factor derived from regression analysis of over 25000 patients who participated in the Major Trauma Outcomes Study [MTOS] (Boyd, Tolson \& Copes, 1987:372). The sum of these products consti- 
tutes the RTS, which comprises a range of scores from 0 to 8 . The lower the RTS, the lesser the probability to survive. If the RTS is used to triage in the pre-hospital environment, it is suggested by several authors that a trauma patient with a value of less than 4 in any parameter, be taken to a trauma centre (Boyd et al. 1987:373).

As stated earlier, age is an important risk factor in trauma. Age of the trauma patient is considered a significant determinant of physiological reserve, which in turn is related to patient survival (Bion, 1993:11). Studies have shown that cardiovascular compromise associated with increasing age, particularly greater than 55 years, relates significantly to probability to survive. In addition to age, the mechanism of injury (blunt or penetrating) produces different physiological derangements and injury characteristics (Woodford, 2001:6) with resultant influence on the patient's probability of survival.

In combining these four parameters, the TRISS method is useful to quantify the probability of survival (Ps) and to evaluate the outcomes of trauma care. In this study the TRISS method was applied to determine trauma patients' Ps. Woodford (2001:5) however, cautions that Ps is merely a mathematical calculation, which indicates a patient's probability of survival and should not be regarded as an absolute measure of mortality.

\section{PROBLEM STATEMENT}

Several factors which complicate trauma systems development and trauma practice have been identified; the most pertinent being the low priority given to trauma care in the public sector (Van der Spuy, 1996:7). This in turn results in unrepresentative profiles of injury mortality, which may serve as a skewed basis for decision-making. A surveillance project was begun to provide a comprehensive description of the nature and severity of injuries, including mortality data, at a Level 1 Trauma Centre in Johannesburg. The use of the trauma casualty as opposed to hospital wards as the first point of entry into the hospital, was anticipated to provide a more representative profile of trauma. The provision of a severity profile as opposed to a head count of trauma cases will, in turn, enhance the planning of trauma services. According to Van der Spuy
(1996:10), severity profiles are best done by using objective criteria such the Glascow Coma Scale for head injuries, the RTS and the Injury Severity Score (ISS) or an equivalent for assessing trauma. As part of a surveillance project, the study set out to provide comprehensive data for profiling trauma patients and determining their injury severity.

\section{PURPOSE AND OBJECTIVES OF THE STUDY}

The purpose of the study was to describe the morbidity and mortality profile of patients seen, over a one year period, at the Trauma Casualty of an academic hospital in Johannesburg.

The main objectives of the study were to:

- describe the frequencies, distribution and categories of injuries seen in the trauma casualty over a one year period;

- assess the severity of injuries, according to the TRISS method, on admission to the trauma casualty; and

- determine the patient outcomes and/or placement after initial treatment in the trauma casualty.

\section{POPULATION AND SAMPLE}

The study population comprised all patients seen at the trauma casualty of an academic hospital, as determined by entries in the trauma register over a one year period in 2001 ( $\mathrm{N}=16357)$. This population was used to generate data in relation to the frequency, distribution and categories of injuries, and to determine patient outcomes. To collect data on the severity of injuries, a $10 \%$ simple random sample $(n=163)$ was obtained of all patients who were resuscitated ( $n=1$ 619). Criteria for inclusion in the latter population were based on the revised resuscitation protocol of the trauma casualty; the focal criterion being an RTS of 11 or less.

\section{METHODS AND PROCEDURES}

A descriptive survey was used to determine the morbidity and mortality profile of trauma patients between January to December 2001. Data were collected by means of a retrospective record review of the trauma register, hospital statistics and patient records. A check- 
list with items derived from the trauma register and the trauma resuscitation form was used for data recording. A pilot study was done to determine whether the checklist would capture the data needed to meet the study objectives. Twenty patients' records, randomly selected from the trauma register entries over a period of one month, were used to conduct the pilot study.

Data analysis involved the use of descriptive statistics to analyse numerical and categorical data. Indices of injury severity were calculated based on anatomical, physiological, injury and age characteristics to quantify probability of survival. Coefficients in the mathematical formula for these calculations were derived from regression analysis applied to data from the Major Trauma Outcomes Study (MTOS) as described by Boyd et al. (1987:372).

\section{ETHICAL CONSIDERATIONS}

Permission to conduct the study and to access hospital and patient records was obtained from the Chief Executive Officer of the Hospital, the Head of the Trauma Unit and the Registered Nurse in charge of
Trauma Casualty. Ethical clearance was obtained from the University Committee for Research on Human Subjects to ensure compliance with ethical standards.

Patients' names and other identifying characteristics were not documented and records were encoded to ensure anonymity and confidentiality during data collection and reporting. The identity of trauma personnel treating patients and recording such treatment, remained confidential throughout the study.

\section{DISCUSSION OF FINDINGS}

In discussing the findings it is important to note that the trauma unit setting in this study deals exclusively with patient conditions presumed to have been caused by trauma and life-threatening medical- surgical emergencies. Over the years trauma care has evolved into a super speciality, hence trauma teams are adequately skilled to deal with any emergency, including emergencies of non-traumatic/medical origin.

A total of 16357 patients were seen over a period of one year at the trauma casualty, amounting to an average of 1363 per month. Males accounted for $69.3 \%$

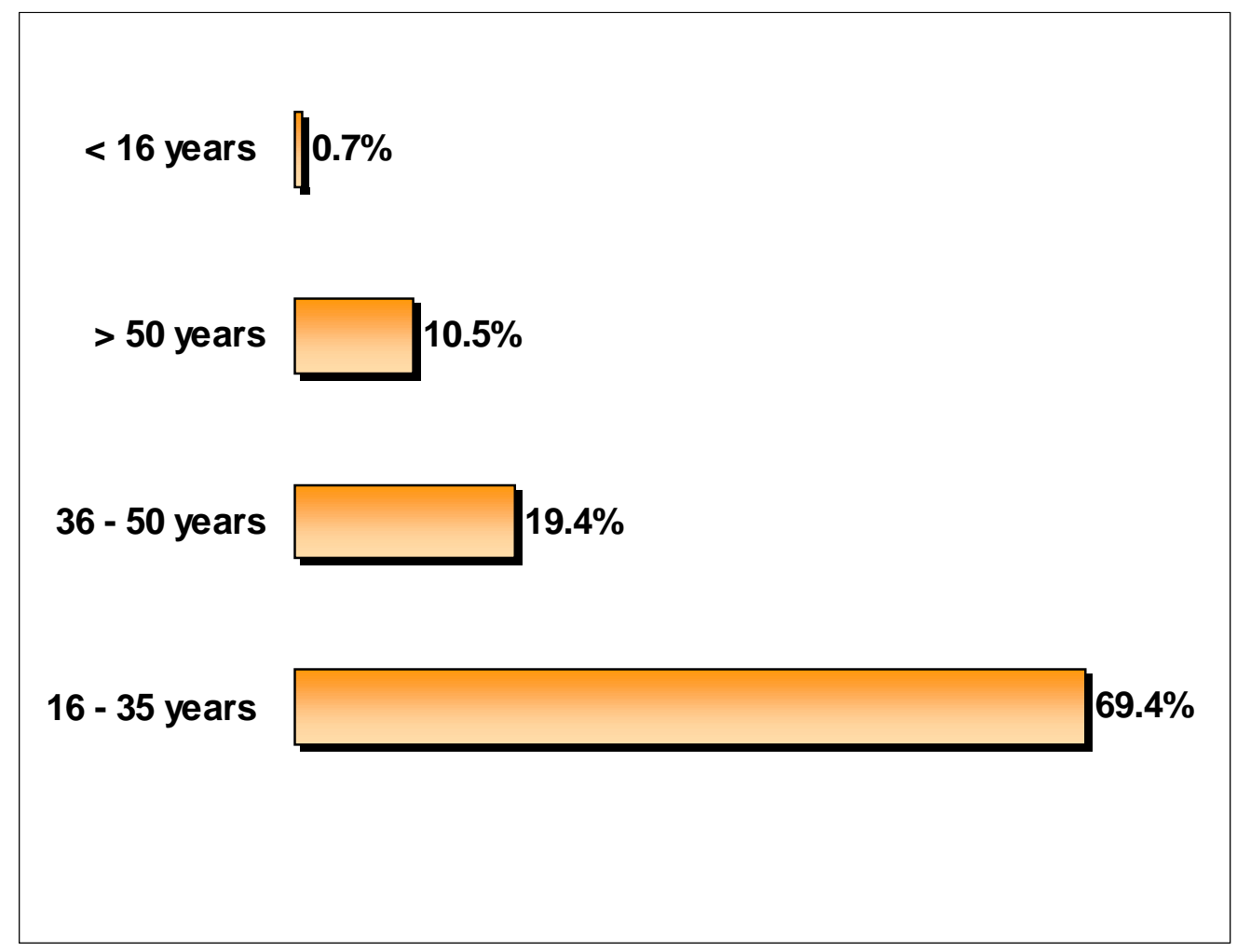

Figure 1: Age distribution of trauma patients 
and females $30.7 \%$ of cases. The majority of patients (69.4\%) were between the ages of 16-35 years and only $0.7 \%$ (109) were below the age of 16 years. A separate paediatric casualty exists for the emergency treatment of children up to the age of 15 years, and treats an average of 1,200 children monthly. All serious childhood injuries such as severe head injuries, poly-trauma, non-responsive haemorrhage and other emergencies, are treated in the (adult) trauma casualty, hence the small percentage of patients below 16 years. Refer to Figure 1 for the age distribution according to four categories.

\section{Frequencies and distribution of cases}

An analysis of the annual caseload showed a distinct difference between weekdays and weekends in relation to patient numbers and time of day. On weekdays, from Monday to Thursday, a total of 7961 patients $(48.7 \%)$ were treated and 8396 (51.3\%) over weekends from Friday to Sunday. While it can be assumed that less patients are seen and treated during the week, the number of cases attended to during the day time period between $08 \mathrm{~h} 00$ and $18 \mathrm{~h} 00$, by far exceeds those seen during the same time period over a weekend. Figure 2 compares the daytime distribution of $59.2 \%$ and $44.2 \%$ between weekdays and weekends respectively. As anticipated, patient frequencies at night, after $18 \mathrm{~h} 00$ until $08 \mathrm{~h} 00$ the following morning, are reversed over weekends, when $55.8 \%$ of cases were treated as compared to $40.2 \%$ in the same time period during weekdays. This pattern is all too familiar to trauma facilities countrywide and is clearly reflected in their statistics. Although these findings have not been analysed on a day-to-day basis, the overall results nevertheless, are consistent with those of the Cape Metropolitan study reported by Van der Spuy and Steenkamp (1996:17). In their study, the weekend loading was considerably higher than weekdays, with Saturdays becoming particularly catastrophic.

\section{Categories of injuries}

Injuries were categorised according the body region/s afflicted (Figure 3). Where two or more body regions were involved, poly-trauma was documented. Approximately 1 in 20 patients seen at the trauma casualty sustained multiple injuries, with an annual count of 944
(5.8\%). Trauma to the limbs, including hip and shoulder injuries, accounted for $45.2 \%$ of all injuries and involved mainly the disciplines of orthopaedic and plastic surgery. Gunshot wounds and injuries sustained during traffic and domestic accidents were the major causes of fractures and dislocations whereas occupational/industrial accidents accounted for a significant demand for plastic surgery to the hands and fingers.

Injuries to the head and neck region accounted for $30.1 \%$ of all trauma cases seen over a one year period. Consistent with popular opinion, the head (including the face) and neck are more prone to injury because of it being the highest point of the body particularly during interpersonal violence. Of the 4918 patients treated with a variety of head, facial, eye, mandibular and neck injuries, an estimated three quarters were inflicted as a result of assault or interpersonal violence. Patient referrals were mainly for neurosurgery and plastic surgery and a small percentage of patients for ophthalmic consultation. Injuries to the chest and abdomen amounted to $9 \%$ (1 471 patients) and $4.9 \%$ (803 patients) respectively. The main mechanisms of injury were penetrating (bullets and stabs) and high speed collisions.

A further 825 patients (5\%) had sustained an array of injuries, which included mainly burns, sjambok injuries, genital injuries, near drowning and poisoning. Sjambok injuries are still a significant factor in trauma care because of its dramatic effect on muscle metabolism, electrolyte balance and renal function and in most cases, can be categorised as poly-trauma.

\section{Severity of injuries}

Almost 10\% (1619) of patients were severely injured and required resuscitation. Of this total, 95.7\% (1549) were adults and $4.3 \%$ (70) were children. Most resuscitation procedures were performed on patients with penetrating chest and abdominal trauma, head injuries and poly-trauma. All patients who were successfully resuscitated, required admission directly to the ICU or via the operating theatre, to the ICU. To determine the injury severity index, a sample of $10 \%(n=163)$ was randomly selected for analysis using the TRISS method. 


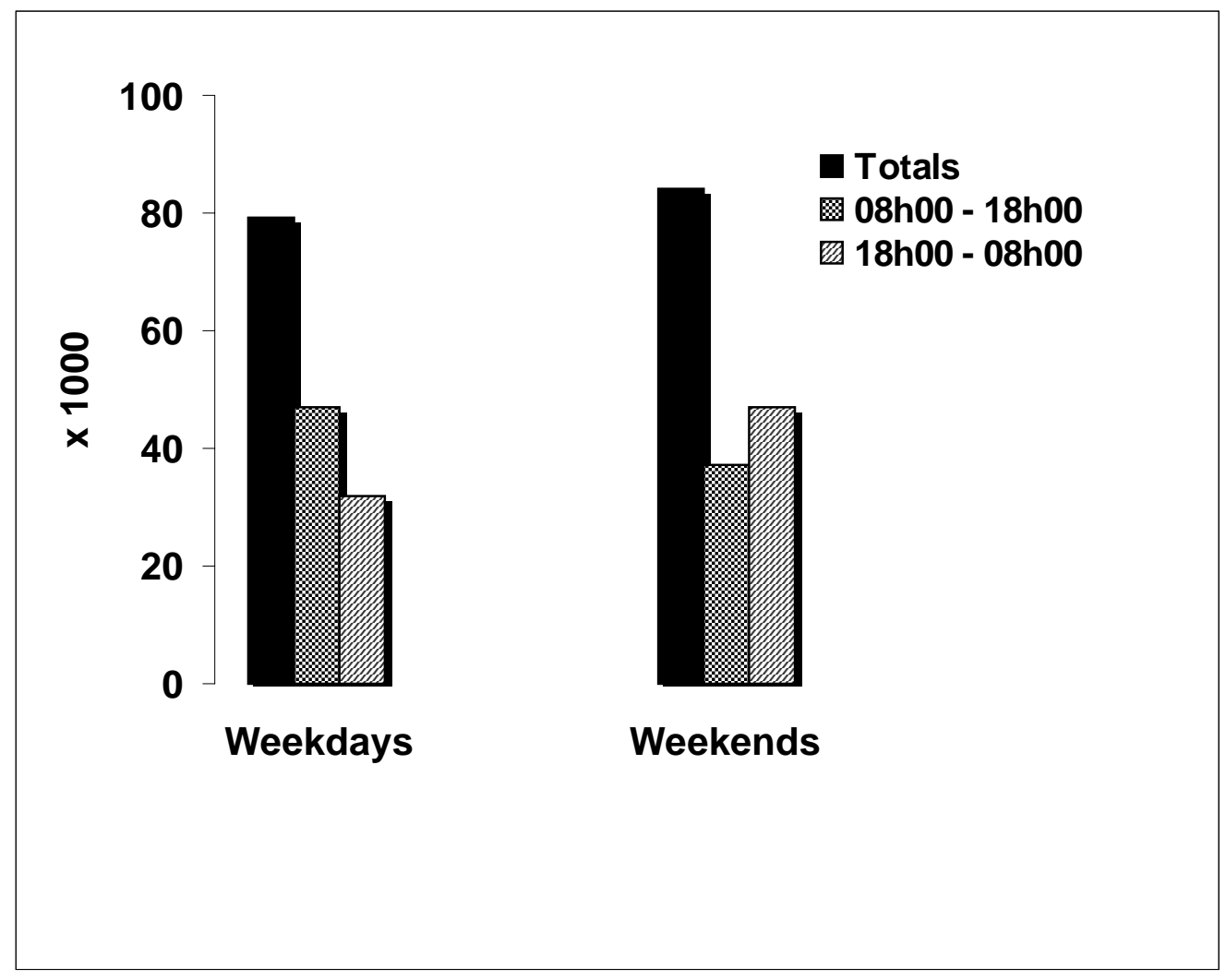

Figure 2: Weekday and weekend attendance

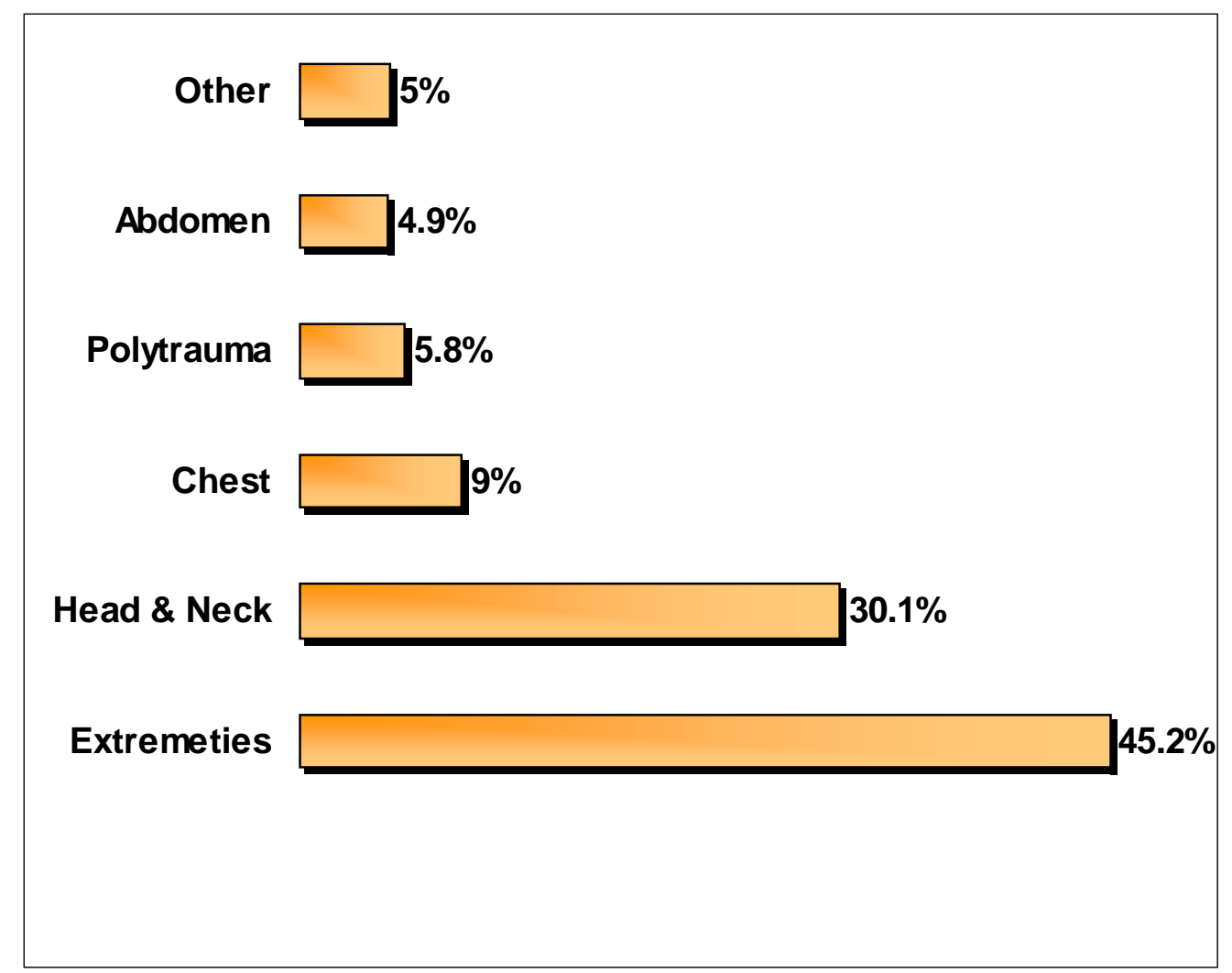

Figure 3: Categories of Injuries 


\section{Results of ISS and TRISS analysis}

Serious injuries occurred mainly in the 25 to 34 year age group ( $n=86$ ), followed by those in the 15 to 24 year age group $(n=40)$. In total, these age groups accounted for $77,3 \%$ of all serious injuries. Males comprised $86 \%$ of the sample of severely injured patients.

The Injury Severity Scores (ISS) were calculated for the sample as depicted in Table 1. The majority, 60.7\% of patients ( $n=99$ ), sustained injuries with an ISS between 16 to 75 and were descriptively classified as serious (16-24), severe (25-40) and critical (41-75). According to Boyd et al. (1987:371) an ISS of 16 is predictive of $10 \%$ mortality, and should ideally be treated at a level 1 trauma centre. In order to apply the TRISS method of analysing injury severity (Table 2 ), the sample was categorised into blunt trauma $(n=52)$ and penetrating trauma $(n=111)$. Close to $15 \%$ of those patients who sustained blunt trauma, had a probability of survival of less than 0.5 or $50 \%$ compared to $10 \%$ who sustained penetrating trauma. The majority of penetrating type injuries were gunshot wounds, stab wounds and those resulting from high speed collisions, inflicting damage mainly to the limbs, chest and abdomen. According to experience and research by Raftopolous, Hayes, Nyman, Haynes, Goosen and Boffard (2001:8) penetrating injuries are the most demanding in terms of clinical resources. Collectively, the majority of seriously injured patients admitted (89.6\%), had a survival probability $>50 \%$.

A total of 28 patients (28.3\%) with an ISS $>15$ died as a result of their injuries. The highest number of deaths occurred in patients with blunt injuries. The mechanism of injury in blunt trauma usually involves a number of forces described earlier, resulting in concealed, multiple injuries, which complicate diagnosis. The number of deaths in patients who had a Ps $>50 \%$ amounted to approximately two thirds $(n=19)$ of these deaths and may be stated as an unfavourable outcome (Cardona et al. 1994:92) and be viewed as preventable. The question of preventable mortality, with or without breaching standards, is an emerging category of mortality in trauma practice (Goosen, 2001:2). This in turn, may impact on the outcomes of severe trauma and the way it is reported and utilised in trauma systems planning.

\section{Overall patient outcomes}

To meet the third study objective, total patient outcomes were determined in relation to patient admission, discharge and death. Of the annual case load, 10017 patients $(61.1 \%)$ had sustained injuries of a nature, which warranted discharge. A few of these patients were required to return the following day to an outpatient department for follow-up treatment. Although not observed in this study, much can be speculated about the appropriateness of attendance by approximately six out of every ten trauma patients. A survey of patients attending an academic hospital in Cape Town showed a similar pattern in that $60.4 \%$ of patients sought "inappropriate trauma care" (Peden, Van der Spuy \& Abrahams, 1996:21). Despite government policy to "regulate" patient attendance at tertiary hospitals through the restructuring of health services and redirecting resources, many patients still seek trauma care at these hospitals. It may be concluded that the majority of trauma patients in this study sustained injuries that warranted trauma care, appropriate for level II trauma centres.

A total of 5141 patients (31.4\%) were admitted to hospital wards with 400 (7.8\%) seriously injured patients admitted to a variety of Intensive Care Units (ICU). Recent cuts in ICU beds and the admission of seriously injured patients to general wards raise questions around the validity of this proportion of ICU admissions. Hence, this result may not be a realistic reflection of patient morbidity.

Mortality data revealed that $1.4 \%$ (221) of patients died as a result of their injuries. Of these patients, 32 (14.5\%) were certified dead on arrival, 128 (57.9\%) died in casualty and 61 patients (27.6\%), who were sent directly to theatre after initial stabilisation in casualty, succumbed in theatre. The mortality profile does not include injury-related deaths in the immediate postoperative period in intensive care units or trauma wards. In view of this fact, these statistics may not be representative of the actual trauma death rate.

The study hospital is a major referral centre for outlying hospitals. It follows that, in less serious cases, several trauma patients are transferred back to their referring hospitals and those with medical benefits, and depending on their condition, are transferred to private hospitals. A total of 552 patients (3.4\%) were transferred to outlying hospitals and local private health 
Table 1: Injury Severity Score (ISS) of Sample $(n=163)$

\begin{tabular}{|l|c|c|}
\hline \multicolumn{1}{|c|}{ ISS Category } & Frequency & Percentage \\
\hline \hline Minor: $1-15$ & 64 & 39.3 \\
\hline Serious: $16-24$ & 29 & 17.8 \\
\hline Severe: $25-40$ & 62 & 38.0 \\
\hline Critical: $41-75$ & 8 & 4.9 \\
\hline TOTAL & 163 & 100 \\
\hline
\end{tabular}

Table 2: TRISS Analysis of Injury Severity $(n=163)$

\begin{tabular}{|c|c|c|}
\hline TRISS Scores & $\begin{array}{c}\text { Blunt Trauma } \\
(\mathbf{n}=52)\end{array}$ & $\begin{array}{c}\text { Penetrating Trauma } \\
(\mathbf{n}=111)\end{array}$ \\
\hline \hline $0-19$ & 4 & 7 \\
\hline $20-39$ & 2 & 3 \\
\hline $40-59$ & 6 & 2 \\
\hline $60-79$ & 10 & 3 \\
\hline $80-99$ & 30 & 96 \\
\hline TOTAL & 52 & 111 \\
\hline
\end{tabular}

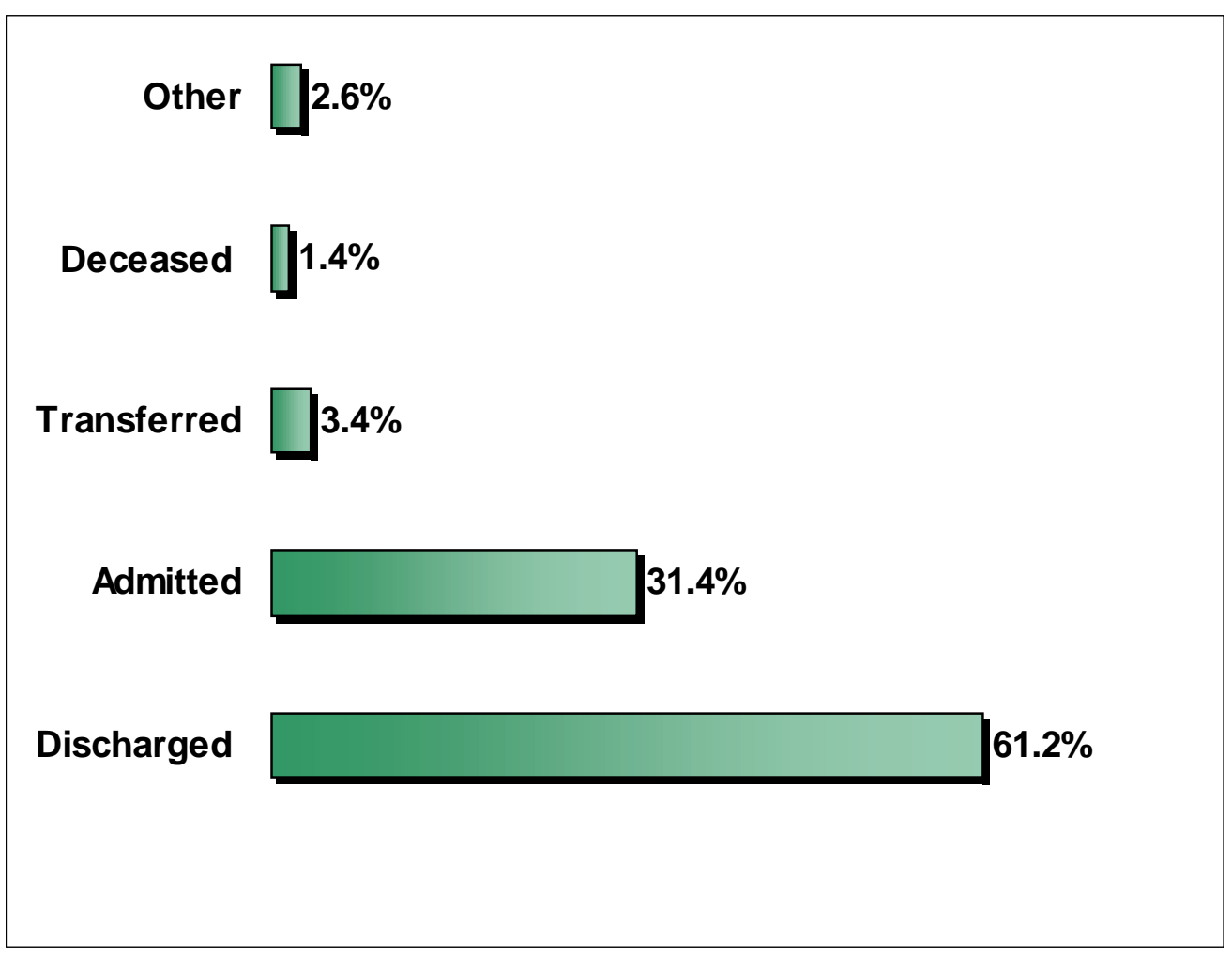

Figure 4: Overall patient outcomes 
facilities. A further 426 patients (2.6\%) either absconded after being assessed and diagnosed (including tests), or refused treatment in casualty after full assessment and diagnosis. Figure 4 depicts a composite picture of patient outcomes.

\section{CONCLUSION}

Its situation within a broader surveillance context makes the results of this survey preliminary. Hence, definitive recommendations for trauma practice, education and research would be premature. The rapidly changing nature and increasing complexity of trauma commands constant review of trauma practices and the development of new and improved methods of trauma scoring systems. Researchers and trauma practitioners generally agree that the TRISS method is one of the major advances in measuring injury severity and trauma outcomes. As research continues to improve the TRISS methodology, one can anticipate an extended use of injury severity indices for rational decision-making in pre-hospital contexts, in-hospital intensive care environments and in trauma patients with the added burden of disease, notably HIV/ AIDS. Quantifying injury severity is integral to the epidemiology of trauma and serves as a much-needed guide to appropriate resource allocation in trauma care.

\section{REFERENCES}

BION, JF 1993: Outcomes in Intensive Care. British Medical Journal, 307:953-954

BOYD, C; TOLSON, M \& COPES, WS 1987: Evaluating Trauma Care: The TRISS method. Journal of Trauma, 27(4):370-378. CARDONA, VD; HURN, PD; MASON, PJ; SCANLON, AM \& VEISE-BERRY, S 1994: Trauma Nursing from resuscitation through rehabilitation. Philadelphia: WB Saunders.

FUHRI, PD 1998: Ambulance and emergency medical services in South Africa: Where are we today? Trauma and Emergency Medicine, 5(4):36-39.

GOOSEN, J 2001: "Outcome of severe trauma in an emerging environment". http://www.wits.ac.za/trauma/tra005.htm (15 September 2001).

MARAIS, S 1998: National Trauma Research Programme (NRTP) of the South African Medical Research Council. Violence in South Africa. Trauma Review, 6(2):1 \& 10.

PEDEN, M; VAN DER SPUY, J \& ABRAHAMS, N 1996: The inappropriate use of tertiary trauma facilities. Trauma and Emergency
Medicine, 13(1):20-21.

RAFTOPOLOUS, S; HAYES, P; NYMAN, C; HAYNES, W; GOOSEN, J \& BOFFARD, K 2001: The epidemiology of change: Johannesburg 1993-1998. http://www.wits.wits.ac.za/trauma/ tra005.htm (15 September 2001).

VAN DER SPUY, J \& STEENKAMP, M 1996: The Cape Metropolitan Study: Some personnel concepts. Trauma and Emergency Medicine, 13(1):12-115.

VURGARELLIS, P \& VAN DER SPUY, J 1996: What trauma data do health policymakers require? Trauma and Emergency Medicine, 13(1):6.

WOODFORD, M 2001: "Trauma scoring". <http://www.tarn.ac.uk/ traumascoring.htm> (8 May 2001). 